\title{
Specific in vitro binding of a plasmid to a membrane fraction of Bacillus subtilis
}

\author{
(Staphylococcus aureus plasmids/pSL103 and pUB110/initiation mutants)
}

\author{
Ronald Korn, Scott Winston, Teruo Tanaka*, and Noboru Sueoka \\ Department of Molecular, Cellular, and Developmental Biology, University of Colorado, Boulder, Colorado 80309 \\ Communicated by William B. Wood, October 14, 1982
}

\begin{abstract}
A model system has been developed to study the in vitro binding of a plasmid to the membrane fraction from $B a$ cillus subtilis. The plasmid DNA molecule used in these studies was pSL103 (8.0 kilobases), a chimeric plasmid consisting of a Staphylococcus aureus plasmid.(pUB110, 4.5 kilobases) and a DNA fragment (3.5. kilobases) from Bacillus pumilus carrying $\operatorname{trp} \mathrm{C}^{+}$gene. This plasmid replicates in $B$. subtilis cells, and its in vivo membrane binding (as well as its replication) is dependent on the product of a DNA initiation gene, dna-1, of B. subtilis. In this paper we demonstrate the in vitro specific binding of exogenous pSL103 to the isolated membrane fraction. This in vitro binding is specific to the origin-containing portion (pUB110) of pSL103. The $\operatorname{trp} C^{+}$. carrying portion neither binds to the membrane fraction nor competes with pSL103 for binding to the membrane fraction in vitro. ColE1 plasmid, which does not replicate in B. subtilis, neither binds to the $B$. subtilis membrane fraction nor competes with pSL103 for binding.
\end{abstract}

Association of the origin of DNA replication of the bacterial chromosome with the membrane has been reported in both Bacillus subtilis (1-6) and Escherichia coli $(7,8)$. This association may serve to regulate in some way the initiation of chromosome replication which is the primary control step in the prokaryotic cell cycle (1). We have tested this hypothesis by determining the effect of initiation-defective mutants of $B$. subtilis on DNA-membrane association (6). In vivo, the membrane association of DNA near the chromosomal origin in $B$. subtilis is dependent on the $d n a-1$ gene product, which is also required for initiation of $B$. subtilis chromosomal replication at the origin. Membrane association and initiation of the plasmid pSL103 in $B$. subtilis are also dependent on the dna-1 gene product (6). The plasmid pSL103 [8.0 kilobases $(\mathrm{kb})$ ] is a chimera between the Staphylococcus aureus plasmid pUB110 (4.5 kb), which provides a replication origin, and a trp $C^{+}$-containing DNA fragment $(3.5 \mathrm{~kb})$ from Bacillus pumilus (9) (see Fig. 2 Inset).

In contrast to the $d n a-1$ mutation (10), the $d n a B 19$ mutation (11) affects only the membrane association and initiation of the $B$. subtilis chromosome and has no effect on the replication or the membrane binding of pSL103 $(6,12)$. The temperature-sensitive initiation mutants $d n a-1$ and $d n a B 19$ carry defects in distinct but closely linked loci, $d n a B I$ and $d n a B I I$, respectively (13). When purified DNA-membrane complex isolated from dna-1 (dnaBI) cells containing pSL103 is incubated in buffer at the nonpermissive temperature, plasmid DNA and DNA near the $B$. subtilis chromosomal origin are selectively released from the complex (6).

In this paper we describe a system in which pSL103-membrane complex can be formed in vitro from purified components. Thus, pSL103 can specifically bind in vitro to the isolated

The publication costs of this article were defrayed in part by page charge payment. This article must therefore be hereby marked "advertisement" in accordance with $18 \mathrm{U}$. S. C. $\$ 1734$ solely to indicate this fact. membrane fraction from B. subtilis. Furthermore, this binding is specific for the origin-carrying half of pSL103-i.e., pUB110.

\section{EXPERIMENTAL PROCEDURES}

Bacterial Strains and Growth Conditions. B. subtilis 168 trp thy (pSL103) (6), 168 trp thy dna-1 (10), 168 trp thy dna-1 (pSL103) (6), and 168 leuA8 metB5 purA16(14) were used. Cells were grown in the $\mathrm{SPC}^{+}$salt medium $(15)$ at $37^{\circ} \mathrm{C}$, except that the strain carrying the dna-1 mutation was grown at $32^{\circ} \mathrm{C}$ in medium supplemented with thymine at $5 \mu \mathrm{g} / \mathrm{ml}$. The cells were grown to $7 \times 10^{7}$ cells per $\mathrm{ml}$ and harvested by centrifugation; frozen cell pellets were stored at $-70^{\circ} \mathrm{C}$.

Radioactive Labeling. Cells were labeled by growing them in the appropriate medium as described above with $\left[{ }^{3} \mathrm{H}\right]$ thymidine $\left(50 \mathrm{Ci} / \mathrm{mmol} ; 1 \mathrm{Ci}=3.7 \times 10^{10} \mathrm{~Bq} ;\right.$ Amersham $)$ at $4 \mu \mathrm{Ci} / \mathrm{ml},\left[{ }^{14} \mathrm{C}\right]$ thymine $(50 \mathrm{mCi} / \mathrm{mmol}$; New England $\mathrm{Nu}-$ clear) at $1 \mu \mathrm{Ci} / \mathrm{ml}$, or $\left[{ }^{14} \mathrm{C}\right]$ leucine $(50 \mathrm{mCi} / \mathrm{mmol}$; New England Nuclear) at $1 \mu \mathrm{Ci} / \mathrm{ml}$. ${ }^{3} \mathrm{H}$-Labeled plasmid prepared by growing 168 trp thy cells harboring the plasmid with $\left[{ }^{3} \mathrm{H}\right]$ thymidine as above had a maximal specific activity of $3.4 \times 10^{4}$ $\mathrm{cpm} / \mu \mathrm{g}$. To increase the specific activity of the plasmid, cells were first grown in the presence of neomycin $(5 \mu \mathrm{g} / \mathrm{ml})$ and thymine $(3-5 \mu \mathrm{g} / \mathrm{ml})$. When the culture reached $7 \times 10^{7}$ cells per $\mathrm{ml}$ (40 Klett units), $\left[{ }^{3} \mathrm{H}\right]$ thymidine was added $(4 \mu \mathrm{Ci} / \mathrm{ml})$ to the culture flask along with hydroxyurea to a final concentration of $0.2 \mathrm{M}$. Hydroxyurea specifically inhibits host chromosomal DNA synthesis but allows the plasmid to continue to replicate; it also increases pSL103 copy number to approximately 200 copies per cell (12). After addition of hydroxyurea and $\left[{ }^{3} \mathrm{H}\right]$ thymidine, the cell culture was allowed to continue growing for $3 \mathrm{hr}(12)$. The cells were then harvested and stored at $-70^{\circ} \mathrm{C}$ until needed. Plasmids were isolated as described below. The specific activity obtained by this procedure was as high as $3 \times 10^{5} \mathrm{cpm} / \mu \mathrm{g}$ of plasmid.

Preparation of Membrane Fraction. Frozen cell pellets from $25 \mathrm{ml}$ of culture were thawed and resuspended in a mixture of $0.5 \mathrm{ml}$ of TKE buffer $(0.02 \mathrm{M}$ Tris, $\mathrm{pH} 8.1 / 0.1 \mathrm{M} \mathrm{KCl} / 1 \mathrm{mM}$ EDTA) (16), $0.1 \mathrm{ml}$ of lysozyme solution $(5 \mathrm{mg} / \mathrm{ml})$, and 0.05 $\mathrm{ml}$ of $0.1 \mathrm{M} 2$-mercaptoethanol. After $15 \mathrm{~min}$ at $32^{\circ} \mathrm{C}, 0.1 \mathrm{ml}$ of $5 \%$ Brij- 58 was added. The solution was allowed to stand at room temperature for $2 \mathrm{~min}$ and then placed on ice. The sample was sheared 10 times by passing it through an 18-gauge needle. Sucrose gradient centrifugation, fractionation, and radioactivity assays were as described (6). The portions of the gradient containing the membrane fraction were pooled.

Plasmid DNA Isolation. Cell pellets from a 1.2-liter culture of $B$. subtilis cells harboring pSL103 grown to the stationary phase in tryptophan-free medium were resuspended in $2 \mathrm{ml}$ of

Abbreviation: kb, kilobase(s)

* Present address: Mitsubishi-Kasei Institute of Life Sciences, Machida-shi, Tokyo. 
0.5 $\mathrm{M}$ sucrose/ $0.05 \mathrm{M}$ Tris, $\mathrm{pH}$ 8.0. After incubation for $30 \mathrm{~min}$ at $37^{\circ} \mathrm{C}, 2.5 \mathrm{ml}$ of $0.25 \mathrm{M}$ EDTA (pH 8.0) was added and the cells were incubated for $5 \mathrm{~min}$ at room temperature. Then, 8 $\mathrm{ml}$ of $1 \%$ Brij-58/0.4\% deoxycholate/0.05 M Tris/0.025 M EDTA, pH 8.0, was added and the cell lysate was incubated for $10 \mathrm{~min}$ on ice. The solution was centrifuged for $20 \mathrm{~min}$ at 18,000 $\mathrm{rpm}$ in a Sorvall SS34 rotor at $10^{\circ} \mathrm{C}$. The supernatant was made $0.88 \mathrm{~g} / \mathrm{ml}$ in $\mathrm{CsCl}$ and $750 \mu \mathrm{g} / \mathrm{ml}$ in ethidium bromide and centrifuged in a Beckman $75 \mathrm{Ti}$ rotor for $44 \mathrm{hr}$ at $42,000 \mathrm{rpm}$ at $20^{\circ} \mathrm{C}$. The plasmid DNA was visualized by UV fluorescence and the band was removed with a syringe and 20-gauge needle. Ethidium bromide was removed by extraction with $n$-butyl alcohol and the solution was dialyzed against 4 liters of $0.1 \mathrm{M}$ ammonium carbonate. The plasmid DNA was either concentrated by ethanol precipitation or by lyophilization to dryness. The DNA was then resuspended in the appropriate buffer. For radioactively labeled plasmid DNA, the $\mathrm{CsCl} /$ ethidium bromide gradients were divided into 30 fractions, and $0.015 \mathrm{ml}$ was removed from each fraction for assay of radioactivity. The pooled DNA fractions containing plasmid were treated as above. The purity of the plasmid was examined by agarose gel electrophoresis (17).

In Vitro Binding. The isolated membrane fraction from 35 $\mathrm{ml}$ of culture was dialyzed against $1.5 \mathrm{mM}$ sodium citrate/15 $\mathrm{mM} \mathrm{NaCl} / 1 \mathrm{mM}$ EDTA overnight and concentrated to approximately $1.5 \mathrm{ml}$ against polyethylene glycol 6000 (PEG 6000 ). The concentrated membrane fraction was incubated at $45^{\circ} \mathrm{C}$ for $10 \mathrm{~min}$. Purified DNA was then added and the mixture was kept at $45^{\circ} \mathrm{C}$ for $5 \mathrm{~min}$. This preincubation of the membrane fraction at $45^{\circ} \mathrm{C}$ was necessary for pSL103 binding to the membrane fractions isolated from both $d n a-1$ and $d n a-1^{+}$cells (unpublished data). For the time course experiments shown in Table 3, time points were taken by diluting the sample 1:10 in TKE buffer at $0^{\circ} \mathrm{C}$. The samples were then centrifuged in sucrose gradients for $3 \mathrm{hr}$ at $25,000 \mathrm{rpm}$ at $4^{\circ} \mathrm{C}$ in an SW 27 rotor as described $(6,16,17)$. The samples were divided into 25 fractions and aliquots $(0.4-1 \mathrm{ml})$ were assayed for trichloroacetic acid insoluble radioactivity.

\section{RESULTS}

Binding of Exogenous pSL103 to Membrane in Vitro. We attempted to establish an in vitro DNA-membrane binding system specific for $\mathrm{pSL103}$. The membrane fraction labeled with either $\left[{ }^{14} \mathrm{C}\right]$ leucine or $\left[{ }^{14} \mathrm{C}\right]$ thymine was purified from $168 \mathrm{trp}$ thy dna-1 cells at $32^{\circ} \mathrm{C}$. These cells did not harbor pSL103. Mixing the membrane fraction and the isolated $\left[{ }^{3} \mathrm{H}\right] \mathrm{pSL} 103$ and incubating at $32^{\circ} \mathrm{C}$ did not lead to the formation of membraneplasmid complex. A heat treatment was necessary. Thus, the membrane fractions were heated for $10 \mathrm{~min}$ at $45^{\circ} \mathrm{C}$, and then purified $\left[{ }^{3} \mathrm{H}\right] \mathrm{pSL} 103$ was added to the $\left[{ }^{14} \mathrm{C}\right]$ thymine-labeled fraction. Five minutes later, an aliquot was removed from the $45^{\circ} \mathrm{C}$ incubation and diluted $1: 10$ at $0^{\circ} \mathrm{C}$. This is the 0 -min incubation sample shown in Table 1 . The remainder of the sample was incubated at $32^{\circ} \mathrm{C}$ for $30 \mathrm{~min}$ and then diluted as above.

To determine the number of plasmid molecules bound to the membrane fraction at $32^{\circ} \mathrm{C}$, the samples were centrifuged in sucrose gradients. A typical sedimentation profile of endogenous chromosomal $\left[{ }^{14} \mathrm{C}\right] \mathrm{DNA}$ and that of exogenously added $\left[{ }^{3} \mathrm{H}\right] \mathrm{pSL} 103$ are shown in Fig. $1 A$. As shown in Fig. $1 B$, under the same conditions, $94 \%$ of the $\left[{ }^{14} \mathrm{C}\right]$ leucine label of the isolated membrane fraction sedimented to the previously observed membrane position, indicating that the membrane particles remain virtually intact after the reisolation procedure, which includes overnight dialysis, volume reduction with PEG 6000 , and heat treatment at $45^{\circ} \mathrm{C}$. However, the majority of originally membrane-bound chromosomal DNA no longer sedimented in

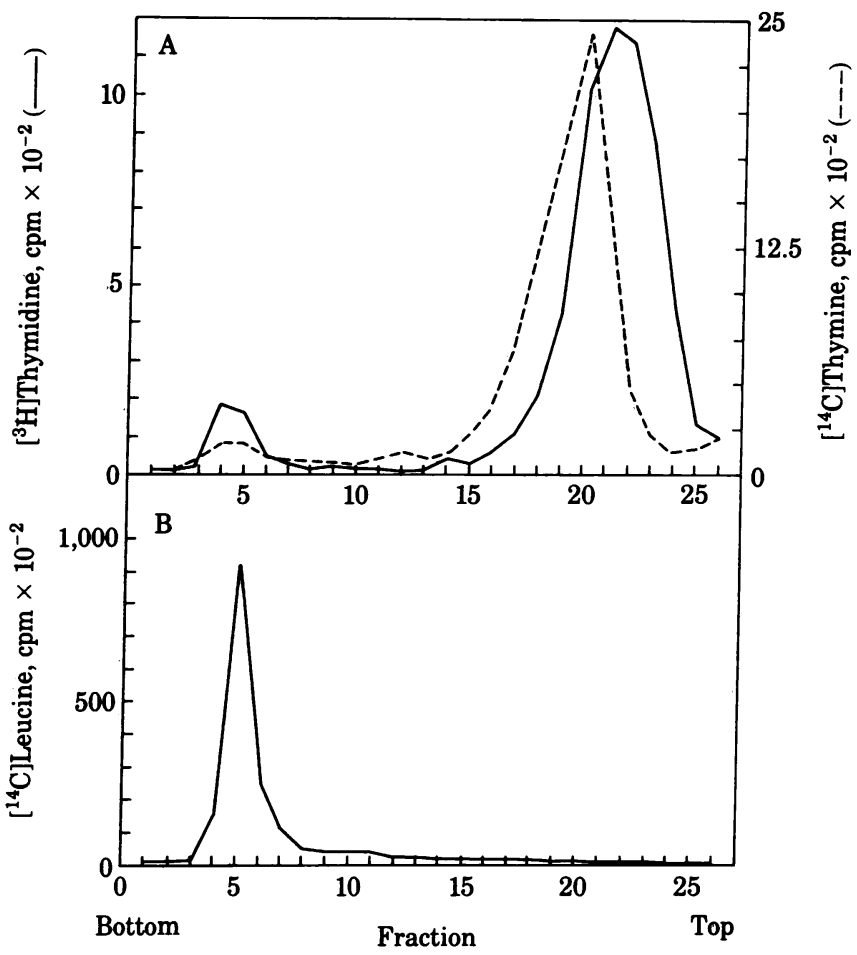

Fig. 1. (A) In vitro binding of exogenous $\left[{ }^{3} \mathrm{H}\right] \mathrm{pSL} 103$ to the isolated membrane fraction. Membrane fraction was isolated from a $25-\mathrm{ml} \mathrm{cul-}$ ture of 168 thy trp dna-1 cells labeled at $32^{\circ} \mathrm{C}$ with $\left[{ }^{14} \mathrm{C}\right]$ thymine $(1 \mu \mathrm{Ci} /$ $\mathrm{ml}$ ). The fraction was dialyzed overnight against $\mathrm{H}_{2} \mathrm{O}$ at $4^{\circ} \mathrm{C}$ and concentrated to approximately $1.5 \mathrm{ml}$ by dialysis against polyethylene glycol 6000 (PEG 6000). The membrane fraction was heated at $45^{\circ} \mathrm{C}$ for $10 \mathrm{~min}$. Purified $\left.{ }^{3} \mathrm{H}\right] \mathrm{pSL} 103(10,000 \mathrm{cpm} / \mu \mathrm{g})$ was added to the membrane fraction in saturating amounts (approximately $2,500 \mathrm{~mol}-$ ecules per cell equivalent of membrane fraction) at $45^{\circ} \mathrm{C}$ for $5 \mathrm{~min}$ longer. The sample was shifted to the permissive temperature $\left(32^{\circ} \mathrm{C}\right)$ for $30 \mathrm{~min}$ and diluted $1: 10$ in TKE buffer at $0^{\circ} \mathrm{C}$. (The temperature of the diluent had no effect on the results-i.e., dilution at $32^{\circ} \mathrm{C}$ gave identical results.) The samples were layered on a 5-20\% linear sucrose gradient with a $62 \%$ sucrose shelf and centrifuged at $20,000 \mathrm{rpm}$ at $4^{\circ} \mathrm{C}$ for $3 \mathrm{hr}$ in a Beckman SW 27 rotor. The gradients were fractionated into 25 tubes (approximately $1.2 \mathrm{ml}$ per tube) from the bottom of the gradient with a peristaltic pump. The entire sample was assayed for trichloroacetic acid-precipitable counts. The solid line is the $\left[{ }^{3} \mathrm{H}\right]$ plasmid profile. The dashed line represents the $\left[{ }^{14} \mathrm{C}\right]$ thymine profile for the host DNA. (B) Sedimentation profile of membrane fraction isolated from dna-1 cells grown in the presence of $\left[{ }^{14} \mathrm{C}\right]$ leucine. $\left[{ }^{14} \mathrm{C}\right]$ Leucine-labeled membrane fraction was isolated by sucrose gradient centrifugation, incubated at $45^{\circ} \mathrm{C}$, and centrifuged again in exactly the same way as the thymine-labeled sample in $A$.

the absence of the membrane fraction [purified pSL103 DNA sediments at the top of the sucrose gradient (17)]. Therefore, the amount of ${ }^{3} \mathrm{H}$-labeled pSL103 found in the membrane fraction region of the gradient is proportional to the number of plasmid molecules bound to the membrane fraction in vitro.

The number of plasmid molecules bound per cell equivalent of membrane was computed in the following manner (see also Table 1). The total number of pSL103 molecules in the gradient was calculated from the amount of ${ }^{3} \mathrm{H} \mathrm{cpm}$ in the gradient and the known specific activity $(\mathrm{cpm} / \mu \mathrm{g})$ of the plasmid. The number of cell equivalents of membrane fraction in each gradient was calculated from the original number of cells used to produce the ${ }^{14} \mathrm{C}$-labeled membrane fraction and the total ${ }^{14} \mathrm{C} \mathrm{cpm}$ in the gradient (Table 1). The term "cell equivalents of membrane" denotes the actual number of cells from which a specific amount of membrane fraction was prepared.

The number of plasmids bound in vitro per cell equivalent 
Table 1. In vitro binding of pSL103 to membrane fraction from dna-1 cells

\begin{tabular}{|c|c|c|c|c|c|}
\hline $\begin{array}{l}\text { Incubation } \\
\text { time, min }\end{array}$ & $\begin{array}{c}{ }^{3} \mathrm{H} \text { label } \\
\text { bound,*\% }\end{array}$ & $\begin{array}{l}\text { pSL103 added, } \\
\text { no./gradient }{ }^{\dagger}\end{array}$ & $\begin{array}{l}\text { pSL103 bound, } \\
\text { no./gradient }{ }^{\ddagger}\end{array}$ & Cell equiv§ & pSL103 bound \\
\hline \multicolumn{6}{|c|}{ Experiment 1} \\
\hline 0 & 1.2 & $1.2 \times 10^{11}$ & $1.4 \times 10^{9}$ & $8.6 \times 10^{7}$ & 16.3 \\
\hline 30 & 2.6 & $1.3 \times 10^{11}$ & $3.4 \times 10^{9}$ & $9.8 \times 10^{7}$ & 34.7 \\
\hline \multicolumn{6}{|c|}{ Experiment 2} \\
\hline 0 & 10.6 & $5.2 \times 10^{10}$ & $5.5 \times 10^{9}$ & $3.7 \times 10^{8}$ & 14.9 \\
\hline 30 & 15.8 & $7.9 \times 10^{10}$ & $1.2 \times 10^{10}$ & $4.9 \times 10^{8}$ & 24.5 \\
\hline
\end{tabular}

Membrane fraction was isolated from ${ }^{14} \mathrm{C}$-labeled $d n a-1$ cells grown at $32^{\circ} \mathrm{C}$, concentrated to approximately $1.5 \mathrm{ml}$, and incubated at $45^{\circ} \mathrm{C}$ for $10 \mathrm{~min}$. Purified $\left[{ }^{3} \mathrm{H}\right] \mathrm{pSL} 103$ (approximately $10,000 \mathrm{cpm} / \mu \mathrm{g}$ in experiment 1 or $175,000 \mathrm{cpm} / \mu \mathrm{g}$ in experiment 2) was added to the membrane fraction and the mixture was allowed to incubate for $5 \mathrm{~min}$ at $45^{\circ} \mathrm{C}$. Half of the sample was diluted 1:10 in TKE buffer and kept on ice while the other half was shifted to $32^{\circ} \mathrm{C}$ for $30 \mathrm{~min}$ and then diluted. The samples were fractionated and assayed for trichloroacetic acid-precipitable counts.

* To membrane fraction, $\left({ }^{3} \mathrm{H} \mathrm{cpm}\right.$ in membrane fraction $/{ }^{3} \mathrm{H} \mathrm{cpm}$ in gradient $) \times 100$.

$+\left({ }^{3} \mathrm{H} \mathrm{cpm}\right.$ in gradient $\times$ no. of pSL103 per $\left.\mu \mathrm{g}\right) /{ }^{3} \mathrm{H}$ cpm per $\mu \mathrm{g}$ of pSL103.

$\ddagger($ Column $2 \times$ column 3 ) $/ 100$.

${ }^{8}$ Number of cell equivalents of membrane fraction per gradient, $=\left({ }^{14} \mathrm{C} \mathrm{cpm}\right.$ in gradient $\times$ no. of cells

in entire experiment) $/{ }^{14} \mathrm{C} \mathrm{cpm}$ in entire experiment.

१ Number of plasmids bound per cell equivalent of membrane fraction, = column 4 /column 5 .

of membrane was similar to the number found in vivo. With the assumption that the copy number per cell of pSL103 in B. subtilis is 40 (9), approximately $75 \%$ of the plasmid molecules in each cell ( 30 plasmids) are found in the membrane fraction of dna-1 cells at $32^{\circ} \mathrm{C}$.

With the assumed copy number of 40 for pSL103, the amount of plasmid added during these in vitro experiments was 2- to 3 -fold in excess of the copy number. However, the degree of excess had no effect on the number of the plasmids bound, indicating that, under our binding conditions, saturation of the binding sites was reached effectively. This result suggests that the cell has a fixed capacity to accommodate pSL103. Therefore, the absolute percentage of plasmids bound to the membrane fraction is dependent upon the amount of plasmids added over saturation-i.e., under more saturating conditions the actual percentage of input plasmids bound will decrease. Because these experiments were done under saturating plasmid conditions, plasmid binding occurred rapidly. Maximal DNA binding occurred within 10 min after shifting the mixture of membrane and the plasmid to $32^{\circ} \mathrm{C}$ (Table 2 ).

Competitive Binding Studies Using ColE1 and pSL103. It was important to demonstrate that the in vitro binding of pSL103 to membrane was specific for the pSL103 molecule and not a nonspecific DNA-membrane interaction. For this purpose, the $E$. coli plasmid ColE1 was used as a heterologous plasmid DNA molecule. ColEl has a molecular weight of 4.2 $\times 10^{6}(6.4 \mathrm{~kb})$ and does not replicate in $B$. subtilis. If the binding of pSL103 to the membrane is a nonspecific interaction, then ColE1 DNA should also bind to the membrane fraction and compete with pSL103 for membrane binding.
Membrane fraction from $d$ na- 1 cells labeled with $\left[{ }^{14} \mathrm{C}\right]$ thymine was isolated and incubated at $45^{\circ} \mathrm{C}$ for $10 \mathrm{~min}$, divided into three equal samples, and added to tubes preheated at $45^{\circ} \mathrm{C}$ for $10 \mathrm{~min}$, containing (i) $\left[{ }^{3} \mathrm{H}\right] \mathrm{ColE} 1,($ ii $)\left[{ }^{3} \mathrm{H}\right] \mathrm{pSL} 103$, or (iii) $\left[{ }^{3} \mathrm{H}\right] \mathrm{pSL} 103$ plus nonradioactive ColEl in a molar ratio of $1: 10$. The samples were kept at $45^{\circ} \mathrm{C}$ for $5 \mathrm{~min}$ and then were incubated at $32^{\circ} \mathrm{C}$ for $30 \mathrm{~min}$ before dilution. The samples were centrifuged and analyzed as before.

Little or no binding of ColE1 to the membrane fraction occurred (Table 3). However, pSL103 was bound in a typical manner. When pSL103 and ColE1 were present together, the binding of pSL103 to the membrane was not affected by the presence of excess ColEl. Thus, ColEl DNA neither bound to purified membrane fraction from $B$. subtilis in vitro nor competed with pSL103 for binding sites on the B. subtilis membrane. Similarly, rat liver DNA did not compete with pSL103 DNA for binding (data not shown). Some pSL103 consistently bound to the membrane even when the reaction mixture was diluted immediately after the 5 -min incubation at $45^{\circ} \mathrm{C}$, although at a lesser amount than that observed at $32^{\circ} \mathrm{C}$ (Table 3 ). Under the same conditions, however, ColEl DNA did not bind at all. Our previous result shows that some molecules of pSL103 also remain bound to the membrane in vivo at the nonpermissive temperature in dna-1 cells (17). This may be due either to the binding of pSL103 to the membrane during the cooling process or to some binding of $\mathrm{pSL} 103$ at $45^{\circ} \mathrm{C}$.

Binding of pSL103 Is Effected Through pUB110 DNA Fragment. The pSL103 plasmid is a chimera of the $S$. aureus plasmid pUB110 and an EcoRI fragment from B. pumilus containing the $\operatorname{trp} C^{+}$gene (9). Because pUB110 provides the rep-

Table 2. In vitro membrane binding of pSL103 at various times*

\begin{tabular}{cccccc}
\hline $\begin{array}{c}\text { Incubation } \\
\text { time, } \min \end{array}$ & $\begin{array}{c}{ }^{3} \mathrm{H} \text { label } \\
\text { bound, \% }\end{array}$ & $\begin{array}{c}\text { pSL103 added, } \\
\text { no./gradient }\end{array}$ & $\begin{array}{c}\text { pSL103 bound, } \\
\text { no./gradient }\end{array}$ & Cell equiv & pSL103 bound \\
\hline 0 & 3.6 & $1.6 \times 10^{10}$ & $6.1 \times 10^{8}$ & $1.4 \times 10^{8}$ & 4.4 \\
10 & 13.0 & $1.2 \times 10^{10}$ & $1.6 \times 10^{9}$ & $1.4 \times 10^{8}$ & 11.4 \\
20 & 13.0 & $1.2 \times 10^{10}$ & $1.6 \times 10^{9}$ & $1.6 \times 10^{8}$ & 10.0 \\
30 & 13.5 & $1.2 \times 10^{10}$ & $1.6 \times 10^{9}$ & $1.5 \times 10^{8}$ & 10.7 \\
\hline
\end{tabular}

${ }^{14} \mathrm{C}$-Labeled membrane fraction isolated from $d n a-1$ cells was shifted to $45^{\circ} \mathrm{C}$ for $10 \mathrm{~min}$. Purified $\left[{ }^{3} \mathrm{H}\right] \mathrm{pSL} 103(48,000 \mathrm{cpm} / \mu \mathrm{g})$ was added to the membrane fraction at $45^{\circ} \mathrm{C}$ for 5 more min, and an aliquot (time 0 ) was removed and diluted $1: 10$ in TKE buffer at $0^{\circ} \mathrm{C}$. The remaining mixture was shifted to $32^{\circ} \mathrm{C}$, and aliquots were removed at various time intervals and diluted.

* Column headings are as defined in Table 1. 
Table 3. Competition of ColE1 with pSL103*

\begin{tabular}{|c|c|c|c|c|c|}
\hline Sample & $\begin{array}{l}\text { Incubation } \\
\text { time, min }\end{array}$ & $\begin{array}{l}{ }^{3} \mathrm{H} \text { label } \\
\text { bound, \% }\end{array}$ & $\begin{array}{l}\text { pSL103 bound, } \\
\text { no./gradient }\end{array}$ & Cell equiv & pSL103 bound \\
\hline \multicolumn{6}{|c|}{ Control } \\
\hline$\left[{ }^{3} \mathrm{H}\right] \mathrm{ColE} 1$ & $\begin{array}{r}0 \\
30\end{array}$ & $\begin{array}{l}0: 16 \\
0.31\end{array}$ & $\begin{array}{l}5.5 \times 10^{8} \\
5.6 \times 10^{8}\end{array}$ & $\begin{array}{l}6.2 \times 10^{9} \\
6.2 \times 10^{9}\end{array}$ & $\begin{array}{l}0.08 \\
0.09\end{array}$ \\
\hline \multicolumn{6}{|c|}{ Experiment 1} \\
\hline$\left[{ }^{3} \mathrm{H}\right] \mathrm{pSL103}$ & 0 & $13.4^{\circ}$ & $8.8 \times 10^{10}$ & $4.8 \times 10^{9}$ & 18.0 \\
\hline \multirow{3}{*}[{}^{3}\mathrm{H}]{$\mathrm{pSL} 103$ + ColE1 } & 30 & 19.4 & $1.4 \times 10^{11}$ & $5.7 \times 10^{9}$ & 24.5 \\
\hline & 0 & 16.9 & $9.9 \times 10^{10}$ & $6.2 \times 10^{9}$ & 15.0 \\
\hline & 30 & 23.0 & $1.6 \times 10^{11}$ & $5.9 \times 10^{9}$ & 29.3 \\
\hline \multicolumn{6}{|c|}{ Experiment 2} \\
\hline$\left[{ }^{3} \mathrm{H}\right] \mathrm{pSL103}$ & 0 & 18.0 & $4.6 \times 10^{9}$ & $8.4 \times 10^{8}$ & 5.4 \\
\hline & 30 & 27.0 & $3.0 \times 10^{10}$ & $1.4 \times 10^{9}$ & 21.3 \\
\hline$\left[{ }^{3} \mathrm{H}\right] \mathrm{pSL} 103+\mathrm{ColE} 1$ & 0 & 19.0 & $4.1 \times 10^{9}$ & $1.4 \times 10^{9}$ & 2.9 \\
\hline & 30 & 26.0 & $9.4 \times 10^{9}$ & $9.2 \times 10^{8}$ & 10.3 \\
\hline
\end{tabular}

${ }^{14} \mathrm{C}$-Labeled membrane fraction from $d$ na-1 cells was incubated at $45^{\circ} \mathrm{C}$ for $10 \mathrm{~min}$. An aliquot of equal volume was removed from each sample and added to a tube containing $\left[{ }^{3} \mathrm{H}\right] \mathrm{ColE} 1(1,000 \mathrm{cpm} / \mu \mathrm{g})$, $\left[{ }^{3} \mathrm{H}\right] \mathrm{pSL} 103(3,000 \mathrm{cpm} / \mu \mathrm{g})$, or $\left[{ }^{3} \mathrm{H}\right] \mathrm{pSL} 103$ and nonlabeled ColE1 in a 1:10 ratio. The tubes were incubated for 5 min more at $45^{\circ} \mathrm{C}$. Half of each sample was diluted 1:10 in TKE buffer and the remaining half of each sample was shifted to $32^{\circ} \mathrm{C}$ for $30 \mathrm{~min}$ and then diluted. The sample was analyzed as before.

* Column headings are as defined in Table 1.

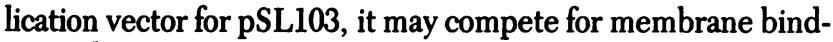
ing with pSL103, whereas the $\operatorname{trp} \mathrm{C}^{+}$fragment may not. To test this possibility, isolated membrane fraction was incubated at $45^{\circ} \mathrm{C}$ for $10 \mathrm{~min}$ and divided equally into tubes containing either various amounts of covalently closed circular pUB110 and $\left[{ }^{3} \mathrm{H}\right] \mathrm{pSL} 103$ molecules or the EcoRI $\operatorname{trp} \mathrm{C}^{+}$fragment and covalently closed circular $\left[{ }^{3} \mathrm{H}\right] \mathrm{pSL} 103$. The samples were incubated for $5 \mathrm{~min}$ more at $45^{\circ} \mathrm{C}$. Each tube was then shifted to $32^{\circ} \mathrm{C}$ for $30 \mathrm{~min}$ and diluted. The samples were analyzed as before.

pUB110 competed with $\left[{ }^{3} \mathrm{H}\right] \mathrm{pSL} 103$ for membrane binding, whereas the linear $E c o R I$ fragment containing the $\operatorname{trp} C^{+}$gene from B. pumilus did not (Fig. 2). The lack of competition by the $\operatorname{trp} C^{+}$fragment is not a function of its conformation-i.e., not a function of being circular or supercoiled (unpublished data). On the basis of these results, we conclude that the in vitro binding of pSL103 to the membrane fraction is specific for the replication vector $\mathrm{pUB1} 10$ and not the $\operatorname{tr} p \mathrm{C}^{+}$portion of the $\mathrm{pSL} 103$ molecule.

\section{DISCUSSION}

The biochemistry of the initiation process of DNA replication in prokaryotic organisms is beginning to be elucidated. Although little is known about the biochemical role of the membrane in the initiation of chromosome replication in bacteria, recent evidence has shown that the DNA-membrane association is necessary in B. subtilis for the initiation of both the host chromosome and pSL103 (6). The study of these DNA-membrane interactions in vitro should prove useful in further studies on the mechanism of initiation and its regulation.

This paper reports the specific in vitro binding of a plasmid, pSL103, to the purified membrane fraction from $B$. subtilis. When the isolated membrane fraction from $B$. subtilis cells, harboring or not harboring pSL103, was heated at $45^{\circ} \mathrm{C}$ and cooled in the presence of exogenously added radioactive pSL103, the exogenous plasmid bound specifically to the membrane fraction. The number of plasmid molecules bound in vitro is comparable to that bound in vivo, and heterologous DNAs such as ColE1 or rat DNA do not bind to B. subtilis membrane or inhibit the binding of pSL103. These results indicate that the membrane component, presumably protein or proteins, re-

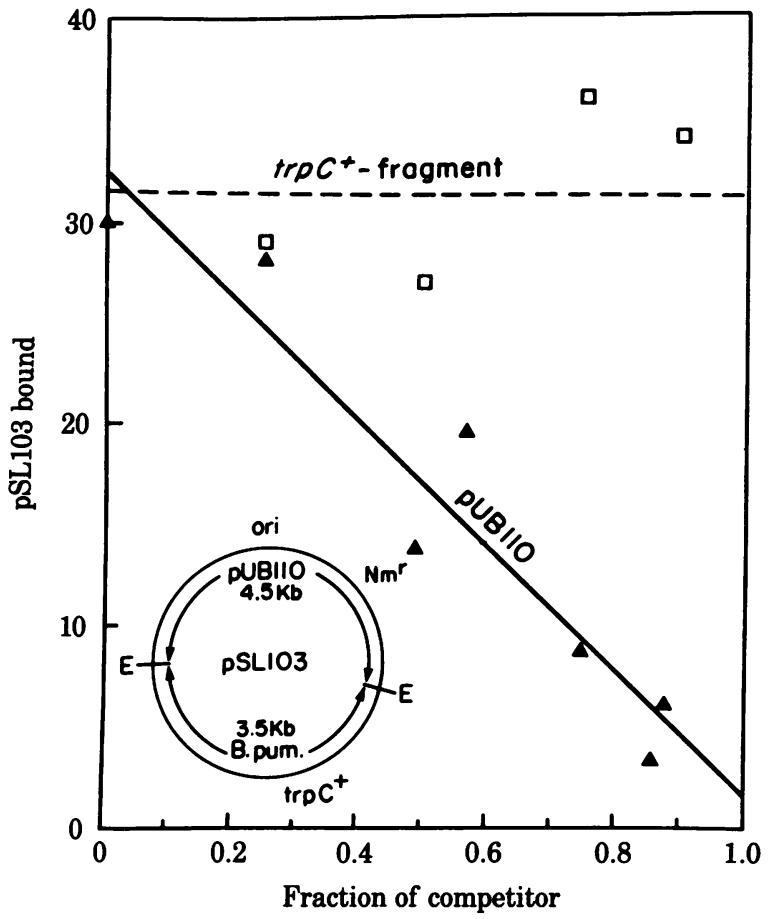

FIG. 2. Competition among pSL103, trp $C^{+}$fragment, and pUB110 for binding to membrane fraction isolated from $d n a-1$ cells labeled with $\left[{ }^{14} \mathrm{C}\right]$ thymine. The membrane fraction was then added to tubes containing either varying amounts of covalently closed supercoiled pUB110 and supercoiled $\left[{ }^{3} \mathrm{H}\right] \mathrm{pSL} 103$ of high specific activity $(145,000$ $\mathrm{cpm} / \mu \mathrm{g}$ ) or the linear $E c \mathrm{RI}$ fragment coding for the $t r p C^{+}$gene from $B$. pumilus and supercoiled $\left[{ }^{3} \mathrm{H}\right] \mathrm{pSL} 103$. The mixtures were allowed to incubate at $45^{\circ} \mathrm{C}$ for an additional $5 \mathrm{~min}$. The samples were then shifted to $32^{\circ} \mathrm{C}$ for $30 \mathrm{~min}$ and diluted $1: 10$ in TKE buffer at $0^{\circ} \mathrm{C}$. Fraction of competitor molecules added was calculated as (number of pUB110 or of $\operatorname{trp} C^{+}$fragment)/(number of pUB110 plus number of pSL103 or number of $t r p C^{+}$fragment plus number of pSL103). pSL103 bound is shown per cell equivalent of membrane complex. (Inset) Map of pSL103. E, EcoRI site; ori and $\mathrm{Nm}^{\mathrm{r}}$, origin of replication and neomycin-resistance marker [locations of ori and $\mathrm{Nm}^{\mathrm{r}}$ on pUB110 as determined by Scheer-Abramowitz et al. (18); their locations relative to the $B$. pumilus fragment of pSL103 are not known]; trp $C^{+}$tryptophan $C$ locus (exact location not known). 
sponsible for the in vitro binding of pSL103 exists in the B. subtilis membrane in approximately the same amount, whether the plasmid exists in the cell or not.

The results of the competitive binding experiments in vitro demonstrate that pSL103 binds to the membrane through the pUB110 portion of this chimeric plasmid. Our results strongly suggest that DNA sequence specificity is involved in the in vitro membrane binding. It is also interesting to note that the binding is mediated by the origin-carrying fragment of pSL103 and not by the $\operatorname{trp} \mathrm{C}^{+}$-carrying fragment.

Recently, we have found that there is no difference in temperature sensitivity between $d n a-1$ and $d n a-1^{+}$cells in the in vitro binding of the plasmid to the membrane fractions and that the in vitro complex is sensitive to salt concentrations above $\mathbf{0 . 2}$ $\mathrm{M} \mathrm{KCl}$ (unpublished data). This is in contrast to the property of the in vivo pSL103-membrane complex we studied previously: the isolated in vivo complex from dna-1, but not the complex from $d n a-1^{+}$, is temperature sensitive in buffer, and the complex from both strains is resistant to high salt concentration (it can be isolated in $4 \mathrm{M} \mathrm{CsCl}$ without substantial degradation) (17). These results indicate that the specific in vitro complex we describe here is only a part of the complete picture of the origin-membrane complex in vivo. Because of the specificity of the binding, it is unlikely that the complex formation in vitro is irrelevant to the in vivo situation. The critical question is whether the type of complex described in this paper exists in the cell in addition to the high-salt-resistant complex or whether the in vitro high-salt-sensitive complex corresponds to a premature complex which becomes the high-salt-resistant one by further processes in vivo.

The reason for the necessity of heat treatment at $45^{\circ} \mathrm{C}$ of the mixture of membrane and plasmids for the in vitro binding is not clear. Some conformational change of a membrane component or the plasmid may be necessary for the binding to occur. In vivo, some factor probably substitutes for the high temperature.

An in vitro site-specific binding of DNA to an isolated membrane protein (protein $B^{\prime}$ ) has been reported in $E$. coli; the protein binds to two sites flanking the chromosome origin (19). The binding is different from the in vitro pSL103-membrane binding in $B$. subtilis reported here in that the $E$. coli origin DNA binds to the protein $B^{\prime}$ in the single-stranded form only, whereas pSL103 or pUB110 binds to the $B$. subtilis membrane in the double-stranded form.

This work was supported by National Science Foundation Grant PCM80-11549 and National Institutes of Health Grant GM28133.

1. Sueoka, N. \& Quinn, W. (1968) Cold Spring Harbor Symp. Quant. Biol. 33, 695-705.

2. Snyder, R. W. \& Young, F. E. (1969) Biochem. Biophys. Res. Commun. 35, 354-362.

3. O'Sullivan, A. \& Sueoka, N. (1972) J. Mol. Biol. 69, 237-248.

4. Yamaguchi, K. \& Yoshikawa, H. (1973) Nature (London) New Biol. 244, 204-206.

5. Sueoka, N. \& Hammers, J. (1974) Proc. Natl. Acad. Sci. USA 71, 4787-4791.

6. Winston, S. \& Sueoka, N. (1980) Proc. Natl. Acad. Sci. USA 77, 2834-2838.

7. Fielding, P. \& Fox, C. F. (1970) Biochem. Biophys. Res. Commun. 41, 157-162.

8. Parker, D. L. \& Glaser, D. A. (1974) J. Mol. Biol. 87, 153-168.

9. Keggins, K., Lovett, P. \& Duvall, E. J. (1978) Proc. Nath Acad. Sci. USA 75, 1423-1427.

10. White, K. \& Sueoka, N. (1973) Genetics 73, 185-214.

11. Karamata, D. \& Gross, J. D. (1970) Mol Gen. Genet. 108, 277287.

12. Shivakumar, A. G. \& Dubnau, D. (1978) J. Bacteriol 136, 12051207.

13. Imada, S., Carroll, L. E. \& Sueoka, N. (1980) Genetics 94, 809823.

14. O'Sullivan, A. \& Sueoka, N. (1967) J. Mol. Biol. 27, 349-368.

15. Anagnostopolos, C. \& Spizizen, J. (1961) J. Bacteriol. 81, 741746 .

16. Yoshikawa, H., Yamaguchi, K., Seiki, M., Ogasawara, N. \& Toyoda, H. (1978) Cold Spring Harbor Symp. Quant. Biol. 43, 569576.

17. Winston, S. \& Sueoka, N. (1980) J. Bacteriol. 142, 339-343.

18. Scheer-Abramowitz, J., Gryczan, T. J. \& Dubnau, D. (1981) Plasmid 6, 67-77.

19. Jacq, A., Lother, H., Messer, W. \& Kohiyama, M. (1980) in Mechanic Studies of DNA Replication and Genetic Recombination, ed. Alberts, B. (ICN-UCLA Symposium on Molecular and Cellular Biology, Academic, New York), Vol. 19, pp. 207-219. 